\title{
COLONIA DACICA SARMIZEGETUSA VOTIVE OFFERINGS. HANDS FOR THE GODS
}

\author{
ADRIANA ANTAL*-GICĂ B $\breve{E}$ EŞTEAN** \\ * National Museum of Transylvanian History, Cluj-Napoca, \\ 2, Constantin Daicoviciu Street, \\ RO-400020 Cluj-Napoca, Romania \\ adrianna.antal@yahoo.com \\ ** Museum of Dacian and Roman Civilisation, Deva \\ 39, 1 Decembrie Street \\ RO-330005, Deva, Romania \\ gica2bae@yahoo.com
}

\begin{abstract}
The purpose of this paper is to highlight some old discoveries from Colonia Dacia Sarmizegetusa (CDS), more precisely a terracotta arm and a few terracotta fingers which, most likely, could be associated with a ritual healing process in local temples. For a complete analysis, this paper approaches the topic of the anatomical votive terracotta phenomenon by examining the contextual relationship between all votive objects and the cult structures which may be connected to them. Even one of the objects under the study has an uncertain discovery context, most of them are connected to the temple of Aesculapius and Hygeia, all of them being anatomical offerings used as a symbol of the suppliant's gratitude for divine healing. This may be the evidence of an organised medical practice within these sanctuaries, for the average person to get health, sanatio, the relative cost of anatomical votive terracotta was low compared to the consultant's fee of a physician.
\end{abstract}

Keywords: Sarmizegetusa, worshipers, anatomical ex-voto, asclepieion

For the Ancient world where danger is by any step, good health represents a basic condition for survival, and, it is expected than Romans put their faith for a cure in the nearest deity who wins renown as providing protection and miracles. A clear evidence for this in Dacia province is the wide popularity of the healing triad, Aesculapius, Hygieia and Telesphorus, and their active role in the asclepieion situated in the capital of the province, Colonia Dacica Sarmizegetusa (Sarmizegetusa, Hunedoara county).

The purpose of this paper is to enrich our knowledge of this asclepieion by highlighting some old discoveries from here published before but without many interpretations about their role in local healing cult. Even some publications discuss the healing gods and their practices ${ }^{1}$ the anatomical ex-voto donation type still remain unexplored, even if these objects presented here are the only evidence for this kind of donation all over the province.

The artefacts that suggest votive offerings for the healing process from the local temple of Sarmizegetusa are presented here by five fragmentary figurate terracottas representing a forearm ${ }^{2}$ and four fingers $\left(\right.$ Fig. 1). $^{3}$

Both the forearm and the fingers seem to be almost life size. For instance the left arm (Fig. 1.al-3, Sarmizegetusa Archaeological Museum, inv. no. 835) preserved partially with palms and broken fingers has a length of $23 \mathrm{~cm}$ and if the piece belongs to a statue (which is unlikely) it would be at the size of a child of at least $1.20 \mathrm{~m}$. Thus, the hypothesis that this arm is a statue fragment must be eluded taking into consideration that the edges from the elbow are intentionally rounded and there are no elements to connect it with other parts of the body (Fig. 1.a3).

${ }^{1}$ IgNa 1935, 51-66; DAiCOVICIU et al. 1975, 225-228; Nicolaus 1981, 43-75; Alicu-Rusu-Pescaru 2000, 32-42; VARGA 2005, 5-8; SCHÄFER 2007, 64-75; ANTAL 2014, 195-206; VARGA 2015, 241-251.
${ }^{2}$ Floca 1967, 50; Alicu et al. 1979, 145, no. 380, Pl. CXXXVIII/380; UNGUREAN 2008, 218, no. 354; ENE 2014, 276, no. 452, pl. 45.

${ }^{3}$ Alicu et al. 1979, 145, no. 381; PAKI-Cociș 1987, 484, no. 9-11, Pl. III/1-2, IV/1; UNGUREAN 2008, 218-219, no. 355-357; ENE 2014, 275-276, no. 448-451, Pl. 45. 
The other ones, representing fingers (Fig. 1.b-d) are lost and preserved only by a drawing, are about the size of an adult (middle fingers $8.5 \mathrm{~cm}$, ring finger $7.8 \mathrm{~cm}$, thumb $9 \mathrm{~cm}$ and the last finger $8.5 \mathrm{~cm}$, without any further explanations or image record) and they could be parts of a hand. It is interesting to note that the fingers from the drawing (middle finger Fig. 1.b and the ring finger Fig. 1.c) do not show any fracture marks on their profile. This could mean either that the fingers are part of an opened palm, which is very unlikely for this type of objects, or rather than they are two index fingers from the left and right hand, having fracture marks on the other side of the profile. Considering the other terracotta figurines known in Dacia province as local made it must be noted that this fragments are well executed, with careful anatomical details which may suggest an import.

Considering the different sizes of the fingers in relation with each other and also in relation with the fore-

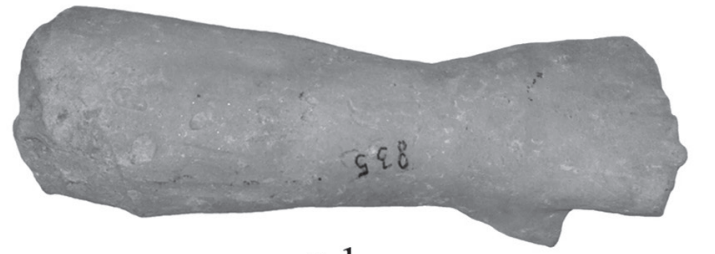

a.1

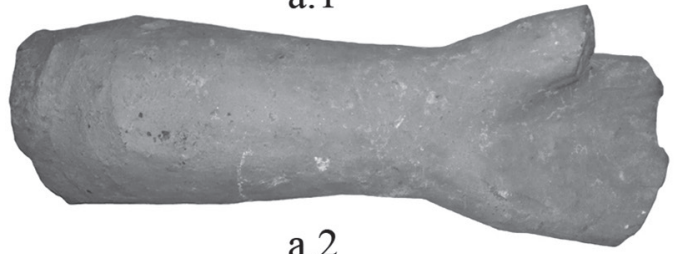

a. 2

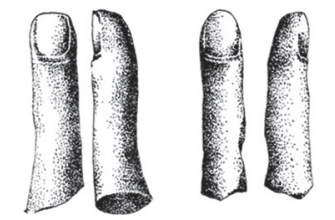

b.

c.

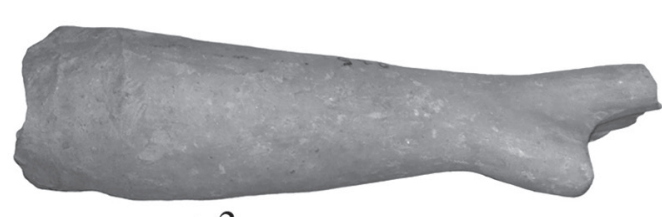

a.3

d.
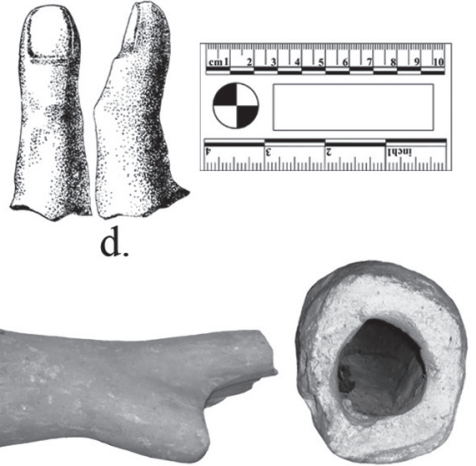

a.4

Fig. 1. Anatomical terracotta ex-voto from Sarmizegetusa. a.1-3: hands with forearm (Sarmizegetusa Archaeological Museum); b, c, d: fingers, now lost (after PAKI-Cociș 1987)

arm, in the hypothesis of life-size statues, it would imply the existence of more than three statues, which is highly improbable, and one would expect some other traces of statue fragments to have survived as well. A terracotta life size statue, being more characteristic for the Etruscan era and not for the provincial art, not only has any precedent in Dacia, but they are also missing from the neighbouring provinces. Therefore, these terracotta body parts are, more likely, some anatomical ex-voto offerings used as a symbol of the suppliant's gratitude for the divine healing. Moreover, as evidence for this kind of ritual are the discovery contexts of this artefacts even one of them is a chance find (the left arm). One finger is coming from the Aesculapius and Hygieia temple and the other three from the opposite temple EM24, with no further explanation.

Though hands as ancient votive anatomical parts are most often made up to the wrist, probably because fingers were more exposed to accidents, there are cases where the forearm appears as well, like in the case of the Sarmizegetusa one. It cannot be resolved whether the rest of the fingers were part of a hand up to the wrist or from a forearm with even an arm and shoulder.

These anatomical parts can be defined as ex-votos, dedicated objects which display or take the form of recognisable parts of the body's interior or exterior (arms, legs, eyes, fingers, hands, feet, uteri, genitals etc.) detached or fragmented from the whole body. Votive offerings illustrating internal organs are mainly created by Romans because their experts have wider anatomical knowledge than the Greeks had, whose healing sanctuaries were rarely furnished by such objects. These kinds of donaria are carved or moulded generally using terracotta, sometimes metal, wood or ivory, and could also be designed in relief on stone or clay plaques, with an accompanying inscription. Ancient anatomical offerings are mostly made in life size, rarely miniaturised, or could be produced in any size between the two, whilst over-life-sized models are uncommon. ${ }^{4}$

\footnotetext{
${ }^{4}$ Petridou 2016, 442; Graham- Draycott 2017, 5-10.
} 
Therefore these anatomical ex-votos represent afflicted, sick or injured parts of the body, and they represent an act of bargain between the individual and the deities, after the healing was put into effect, do ut des (I give, so you may give). All this kind of ex-votos were part of a practice which started to disappear at the end of the $2^{\text {nd }}$ century $\mathrm{AD}$ current that could be linked with the advancement in medical knowledge and to more and more physicians.

A large part of anatomical votive offerings have been made in a technique of mass production by simple craftsmen, sometimes with some peculiar decoration like painting, representing the invalid body part. For the smallfinds in shape of body parts from Sarmizegetusa not any trace of personalization can be detected in disease designing. It also should be noticed that like all the Italic anatomical votive terracottas, neither the forehand nor the fingers are designed to be displayed on a wall like in cases of Greek ones. In most cases they were piles up against statue bases or around altars, instead of being suspended on a wall. ${ }^{5}$ The majority of anatomical terracotta votives were limbs, arms, legs, hands and feet. This is not a surprise in a farming culture of the Sarmizegetusa's landscape, where limbs are most prone to wounds or infections. In fact maybe these worshipers came from lower classes or even from the gladiators for whom the health was the basic condition for their work, and then for survival. ${ }^{6}$

This kind of discovery may be the evidence of an organised medical practice in the sanctuaries of Sarmizegetusa's Area Sacra, for where the average person could receive health, sanatio, by a relative low cost of the anatomical votive terracotta compared that to the consultant's fee of the physicians. ${ }^{7}$

These healing sanctuaries called asclepieion have carefully controlled spaces conducive to healing and fulfilled several of the requirements of institutions created for healing. Water held an important role in picking a place for an asclepieion, beginning with the body preparation for the incubatio ritual, then in the healing process, being directly linked to the notions of purification and cleansing, finally 'washing away' the disease. ${ }^{8}$ The most of the healing achievement were made possible by keeping high hygiene standards, taking bath very often, exercise and diet or therapeutic role of sleep and dreams in applied psychotherapy. Healing was practiced in temples by descendants of Asklepios and sometimes they are performing complicate surgeries which were recording by epigraphical testimonies from Epidaurus. ${ }^{9}$

These healing gods are considered to be present and receptive to hear the problems of the faithfuls. In some cases the patient who needs help addresses directly to the gods ears, according to an old tradition that Aesculapius and Hygieia are part of the 'gods who are listening' $\zeta \varepsilon$ o í $\varepsilon$ ' $\eta \mathrm{K}$ o o i. ${ }^{10}$ This kind of devotion is illustrated by two inscriptions from Sarmizegetusa, dedicated to Aesculapius and Juno, were the ears of divinities are represented in sign of listening, and not because the dedicator has an ear affections(Fig. 2.a, c). ${ }^{11}$ Another interesting altar coming from Apulum (Alba Iulia) has depicted two hands with the inscription (A)escula/peo / et (H)y/gi(a)e / Resti/tuta / [--- (Fig. 2.b). ${ }^{12}$ In this case the inscription does not refer to an injury of the hands being dedicated, instead, for the divine helping hands. As an analogy of this an inscription from the Tiberis Island asklepieion, Rome, dedicated to

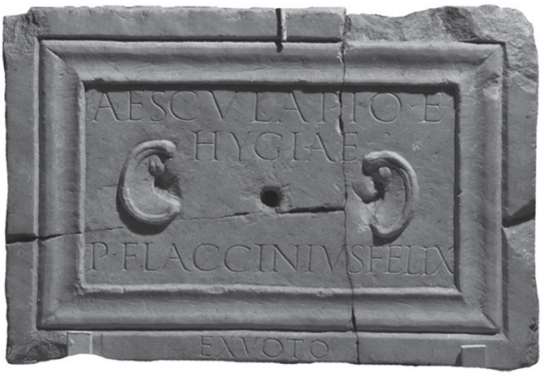

a.

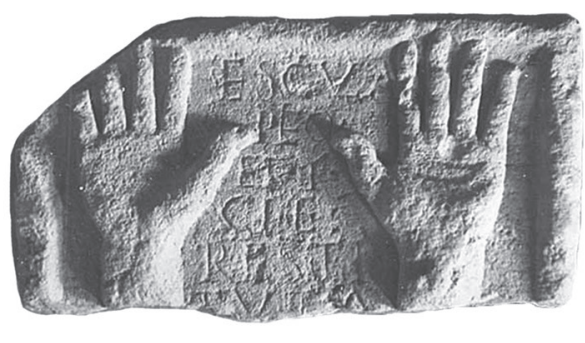

b.

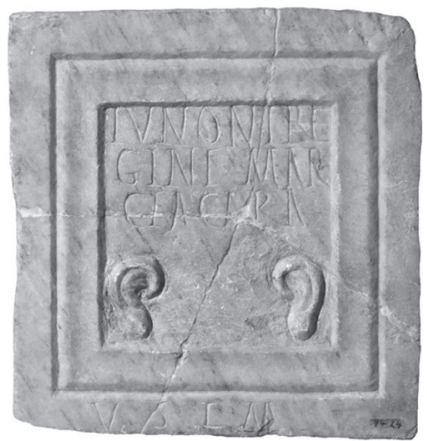

C

Fig. 2. Votive reliefs with ears and hands. a: Sarmizegetusa, Sarmizegetusa Archaeological Museum; b: Apulum, National Museum and Union Hall of Alba Iulia (after O. HARL); c: Sarmizegetusa, National Museum of Transylvanian History, Cluj-Napoca

${ }^{5}$ OBERHELMAN 2014, 136-137.

${ }^{6}$ Comella 1981, 762; Oberhelman 2014, 120

${ }^{7}$ Oberhelman 2014, 30.

${ }^{8}$ VARGA 2015, 247.

\footnotetext{
${ }^{9}$ SIG III, $1168-1169$.

${ }^{10}$ VARGA 2005, 7

${ }^{11}$ CIL III, 986; Alicu et al. 1979, 78, no. 44; PIso 2001, 20.

${ }^{12}$ CIL III, 12558; IDR III/5, 17.
}

Acta Archaeologica Academiae Scientiarum Hungaricae 69, 2018 
Asclepius on a silver anatomical votive by a freedman Neochares Iulianus after "having been saved by your hands from a swelling of the spleen" 13 can be mentioned.

The anatomical offerings are part of a practice that originates certainly from Greece and introduced in Rome once with the cult of Asklepius from Epidauros after the devastating plague (293 B.C.) which has been widespread in the colonies. The connection to Rome is through a cultural contact area between the Greek and Roman spheres of influence, southern Etruria being the first place in Central Italy where anatomical votive terracottas appeared. In this way the anatomical terracotta ex-voto practice is massively naturalized in the provinces and a lot of sanctuary came to life.

One of the most important production centres for anatomical ex-votos is Veii, because its local healing sanctuary in Comunità played a great role in the territory. ${ }^{14}$ Thanks to a donation originating from Veii some terracotta came to possession of the Museum of Cluj-Napoca, including even an ex-voto hand (Fig. 3). ${ }^{15}$

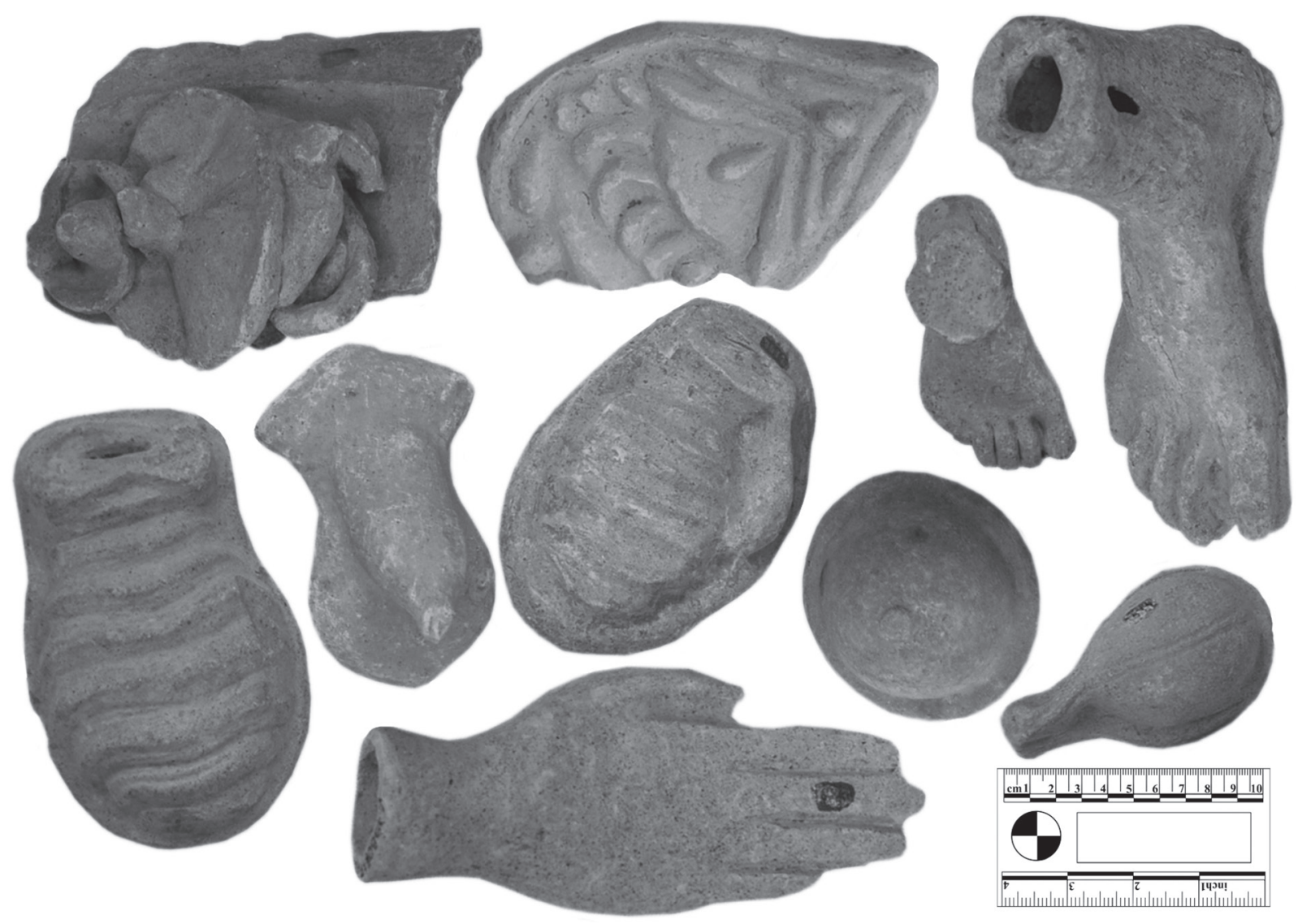

Fig. 3. Anatomical ex-voto from Veii, National Museum of Transylvanian History, Cluj-Napoca

From among the votive body parts of the Empire there can be some good analogies of the Sarmizegetusa's anatomical offerings found, even hands with forearm representation though not so popular for the Romans as the donaria of hands were wide spread throughout the whole Greco-Roman world.

In this regard the sanctuary of Ponte di Nona can be eminent. The religious healing centre (a temple, bath suite, a possible pool and other buildings) located near to Rome along the road to Praeneste was dedicated to an unknown deity. Thousands of votive terracottas, mostly body parts like eyes, feet, hands, arms and legs, were recovered from two pits, one located inside the temple while the other one was excavated in a dump area north of the temple $($ Fig. 4$) .{ }^{16}$

\footnotetext{
${ }^{13}$ SEG 48 (2001) 2170; GIRONE 1998, 154-156.

${ }^{14}$ Lesk Blomerus 1999, 138-139.
}

\footnotetext{
${ }^{15}$ CRIȘAN 1970, 491-496, fig. 1-3.

${ }^{16}$ Griffith 2013, 245-246; OBERHELMAN 2014, 54.
} 
In other three Italian rural sanctuaries, limbs were the most spread discoveries: Fragellae, Nemi and the so-called Thirteen Altars at Lavinium where anatomical votives were put to the altar. The very high number of feet, legs, arms and legs, and just a few other body parts among the finds prove a 'specialization' of these sanctuaries for limb injuries and to reveal their clients, an agrarian population. ${ }^{17}$

Later in Rome, on the Tiberis Island, the permanent home of the healing god, hundreds of such artefacts were found together with the many epigraphic testimonies, medical instruments and figurative monuments. ${ }^{18}$
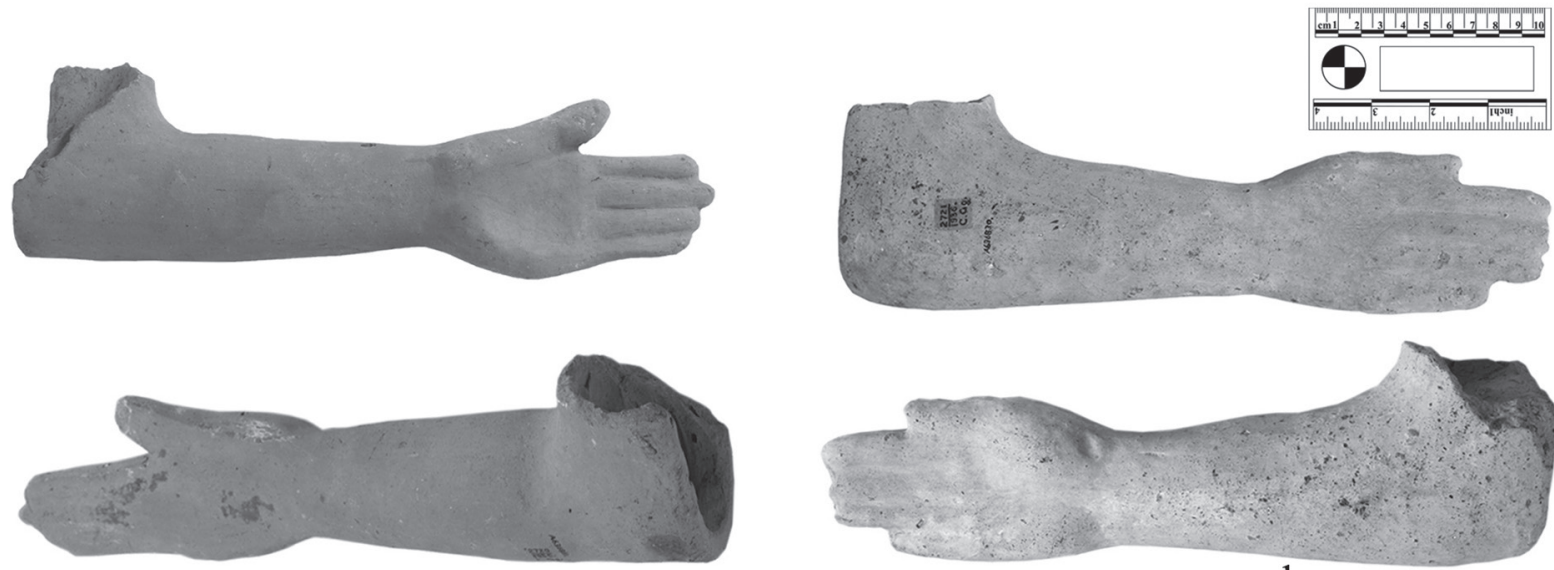

a.

b.

Fig. 4. Hands with forearm terracotta ex-voto from Italy, Wellcome Collection, London

In Gaul anatomical ex-votos appear after Caesar's conquest. The inventory of the provinces of Gaul shows a high concentration among native folks, the Lingons, Eduens and Sulbanectes. All parts of the human body are represented in thousand dedications: heads, torsos, trunks, ponds, legs, feet, arms, hands, and so on. ${ }^{19}$ This type of dedication also are present in Britain, for example at the Lydney temples, Gloucestershire, where in the abaton, a corridor-building with eleven adjoining rooms, anatomical ex-voto were discovered. ${ }^{20}$

In Pannonia in the early imperial period the cult of Aesculapius and his daughter Hygieia could be explain in with their association with the healing cult of Apollo, in Aquincum (Budapest) and its Celtic roots are from the West. Some votive anatomical terracotta from the Hungarian National Museum can be traced back to Brigetio (Szőny) where a sanctuary for the healing gods was established. Also at Savaria (Szombathely) some terracotta statues were found what represent various deformed sick figures, some with emphasized genitalia. ${ }^{21}$ For Moesia Inferior archaeologically two healing centres were identified: the valetudinarium of the Novae fortress and the asclepieion of Glava Panega, but without mentioning any anatomical ex-voto deposits. ${ }^{22}$

Like in the other provinces, healing gods are also very popular in Dacia. A clear evidence of a consistent presence of this cult is represented by the multitude of inscriptions and figurative monuments, most of them coming from Sarmizegetusa. An asclepieion only here was archaeologically authenticated, the other two are mentioned just in epigraphic sources.

One of these places is Ampelum (Zlatna), where the existence of a temple dedicated to healing gods was attested by a building plaque. The inscription mentioning a temple was found in the place called Grui (Alba county), where some substructures of a building were detected. ${ }^{23}$

The existence of another possible sacred area, with more buildings dedicated to various divinities, including healing gods, was assumed based on some inscriptions, ${ }^{24}$ in extra muros of Colonia Aurelia Apulensis, near the Tăuşor Lake. The epigraphic testimonies supposes, among others, a healing complex with multiple buildings, with

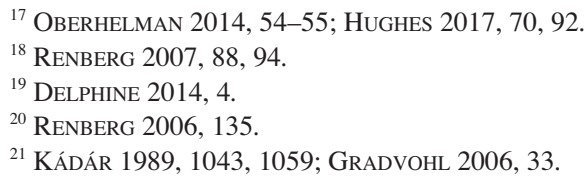

${ }^{22}$ ApaRASCHIVEI 2012, 171-180.

${ }^{23}$ IDR III/3, 280; ALICU-Rusu-PeSCARU 2000, 123.

${ }^{24}$ IDR III/5, 1-21, 30, 31, 32, 33, 34, 35, 36, 47, 199, 220, 223, 247, 297, 356, 363. 
three cellae, a monumental porticus being three times rebuilt, a fountain and a bridge for the connection to the imperial road. ${ }^{25}$

The Aesculapius and Hygieia cult complex of Sarmizegetusa is located outside the city walls to the north. Together with the Liber Pater, Domnus and Domna temple and other buildings with cultic character (EM24, EM16, EM17) it was integrated into the vast local sacred area. ${ }^{26}$ These healing complexes were lifey places with various construction phases, adapted by offerings, by different sacrifices and worshipers, and finally abandoned. In a trapezoidal temenos it has three religious buildings and in the east side of the courtyard there is another building with a pit in the centre, maybe a favissa, where several fragmentary pieces of marble were found ${ }^{27}$ (Fig. 5).

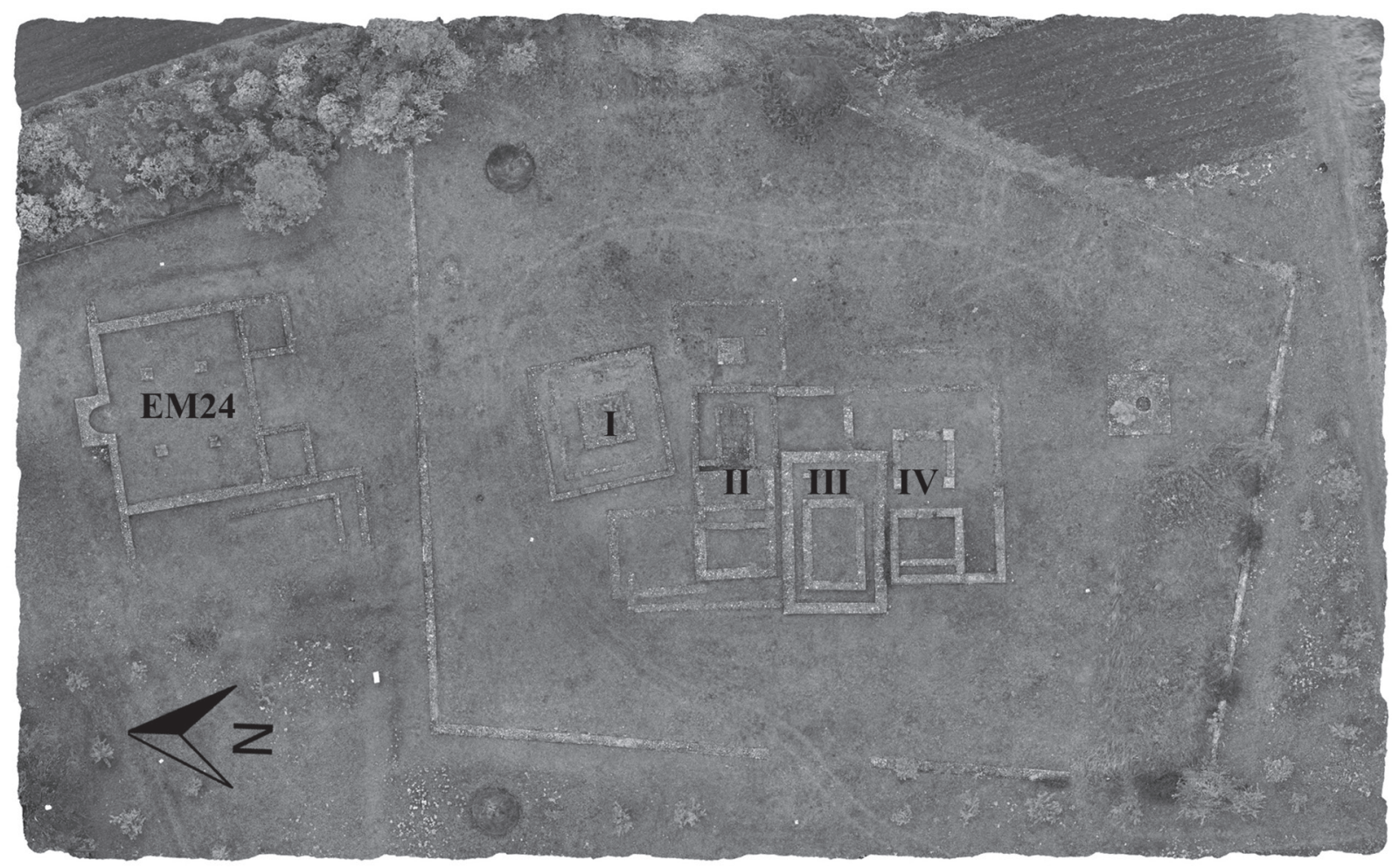

Fig. 5. EM24 and Aesculapius and Hygieia temple from Sarmizegetusa

The proof for the existence of an active asclepieon at Sarmizegetusa are not just the above mentioned anatomical offerings; all the structural features characterizing such institutions are present. There were two fountains erected inside the temenos of the temple, as the presence of water being an essential element in healing treatments. ${ }^{28}$ Also an altar from Sarmizegetusa ${ }^{29}$ suggests that the asclepieion of Pergamum had an important role in the erection of the local asclepieion, the cult probably had been imported from there. After the Marcomannic wars Galenus, a famous doctor from Pergamum visited the Danubian provinces, and perhaps he could be the supposed establisher of the local asclepieion. ${ }^{30}$

In addition to these special attention should be drawn to the incubatio process, which seems to take place in the Sarmizegetusa's healing temple. Dacia is among the few provinces that between the years 106 and $271 \mathrm{AD}$ still had altars offered as response to a demand received in a dream or a vision, which could testify that the healing sleep called incubatio was practiced in the province. ${ }^{31}$ In this regard four inscriptions, were the dedicator uses for-

${ }^{25}$ SzABÓ 2004, 91-114; SzABÓ 2015, 133-134.

${ }^{26}$ DAicoviciu et al. 1975, 225-228; DAicoviciU-Alicu 1981, 73-80; Alicu-Rusu-Pescaru 2000, 32-42; SCHÄFer 2007, 64-75.

\footnotetext{
${ }^{27}$ VARGA 2005, 7.
}

${ }^{28}$ Alicu-Rusu-Pescaru 2000, 40.

${ }^{29}$ CIL III, 1417a; ILS 3854; IDR III/2, 164.

${ }^{30}$ SZABÓ 2008, 99.

${ }^{31}$ SZABÓ 2008, 99. 
mulas such as ex iussu, ${ }^{32}$ ex viso, ${ }^{33}$ and somno monitus ${ }^{34}$ can be mentioned but without any other information. Of the total five inscriptions using these formulas unfortunately only one originates from Sarmizegetusa.

These four inscriptions are the proof that in Dacian asclepieion the 'healing by incubatio'process was practiced. Aesculapius appears in patients dreams, healing them and after that he informs them the price that have to be paid for their recovery. These price could differ depending upon the severity of the disease, e.g. for recovery from blindness probably a bridgework sum is needed, ${ }^{35}$ but for the disease that affected a limb offering of an anatomical terracotta will be enough - depending on welfare of the patient, for the wealthy a construction like a portico, ${ }^{36}$ shrines or inscriptions, and for the modest even lamps could be sufficient.

So the patient must spend a few days in the temple for the incubation waiting for the healing sleep for which Hypnos/Somnus was responsible, playing the role of a guard during the healing process. ${ }^{37}$ And Telesphorus, the twin brother of Hypnos, was in charge for convalescence, fostering the healing from illness. Telesphorus played an active role in the incubatio process and in the case of the asclepieion at Pergamum, incubatio occurred precisely in the Telesphoreion. ${ }^{38}$ The healing divinities Aesculapius, Hygieia, Telesphorus and Hypnos are all present on monuments in the Sarmizegetusa religious landscape. ${ }^{39}$

The field detection of such a special space as incubatio is very difficult, especially since in some asclepieia of the Greco-Roman world the incubatio ritual was held even in open air. ${ }^{40}$ For the Sarmizegetusa asclepieion there is no evidence for such a structure, but it is noteworthy that the fountains are located near building I and II. ${ }^{41}$

Other archaeological data can be related to this kind of activity, like the medical instruments recovered here, mostly spatula which seems however to suggest that the temple was mainly used for consultations, and that the medical procedures took place probably somewhere else. ${ }^{42}$

A great quantity of lamps, more exactly 1245 items, was discovered in the Sarmizegetusa asklepieion, ${ }^{43}$ which could be related to the healing process by incubatio. From among these a large number of pieces were discovered in the north-eastern part of the sanctuary, in front of building I, in the corner of the precinct. ${ }^{44}$ One of these lamps, a very unique candlestick lamp, can be dated between the period of Constantine I and Constantius II (307340 ), which is a clear evidence the cult of the healing gods was practiced after the Aurelian retreat. ${ }^{45}$ Besides the lamps some turibulum for different types of fumigation were also discovered in this area also necessary to get into sleep condition. Some of the lamps being probably some donaria, which was intentionally deposited by priests in favissae near the temple, show no traces of use, when the number of donated lamps outgrows their allotted space in the temple. ${ }^{46}$

EM24 building is at close vicinity of the healing complex, a few meters from the northern side of the temenos, where other anatomical fragments were excavated. Some buildings were located inside the temenos of the Sarmizegetusa sacred space, such as EM24, EM16 or EM17, though they were considered to be places of worship, there are no epigraphic or archaeological indications of the titular deity. Based on some discoveries EM24 was considered a storehouse for festive banquets and devotional gifts, ${ }^{47}$ but after a more thorough complete analysis, and considering its proximity to the healing temple, a relation between the two may turn out to be.

Summing up the above, this research is just a first step in the process of rebuilding the religious phenomena of the cult places of the Sarmizegetusa healing gods. For reconstructing their religious experience it's necessary to reconsider the architecture of the four building of the healing complex, the interior structure and the identification and localization of the cultic equipment. In this way the place for incubatio, the missing place from the healing process could be recovered.

${ }^{32}$ CIL III, 975; ILS 7146; IDR III/5, 6.

${ }^{33}$ CIL III, 987; IDR III/2, 159, III/5, 2; AE1914, 110; ILS,

3847.

${ }^{34}$ CIL III, $1614=8044$; IDR III/5, 13, 220; AE, 1993,

1337.

${ }^{35}$ SzABÓ 2008, 103-104.

${ }^{36}$ AE 1993, 1337; IDR III/5, 13.

${ }^{37}$ ANTAL 2014, 201; VARGA 2015, 244.

${ }^{38}$ DEONNA 1955, 54-55.

${ }^{39}$ ANTAL 2014, 197-198, Pl. I/1-6.

${ }^{40}$ Edelstein 1945, no. 755, 757.
${ }^{41}$ Daicoviciu-Alicu 1981, 73-80; Alicu-Rusu-Pescaru 2000, 36, 40 .

${ }^{42}$ Alicu-Cocis 1989, 228.

${ }^{43}$ ALICU 2006, 64-189.

${ }^{44}$ Alicu 1994, 10; SCHÄFER 2007, 67.

${ }^{45}$ Alicu-Nemeș 1977, 34; VARga 2005, 7.

${ }^{46}$ Alicu 1985, 78

${ }^{47}$ Alicu-Rusu-Pescaru 2000, 104-109; SCHÄFER 2007, 73.

${ }^{48}$ LeSK Blomerus 1999, 123. 
The appearance of such discoveries in the capital of Roman Dacia can be attributed to the influences of the north-western provinces brought here by colonists or soldiers from their homeland. However, some remarks have to be made related to the theme. Even if it became clear that the terracotta fragments studied here are the evidence of anatomical ex-votos, it is unusual that only these hand elements have appeared so far. Following the abovementioned analogies we could see that these ex-votos never appear isolatedly and even if it was a sanctuary specialized only on limb injuries for agrarian population customers, they should have appeared in a larger number together with other categories of body parts, for example legs. In addition to this sanctuaries with limb injury specialization are very rare, most often all kinds of injuries or illness were treated, so all categories of anatomical ex-votos, mostly sexual organs, the cult of fertility are most present.

Probably these offerings were erected by a colonist with some hand injuries, a newcomer from the northwestern provinces, being already familiar with such a type of the donation. Because of this late period (106-271 $\mathrm{AD}$ ) when the incubatio process started also to fade in the provinces this custom with anatomical ex-voto probably had no deeper roots in Dacia. But even if there are only few anatomical votive offerings in relation with the healing process, there is a clear evidence for the popularity of the Aesculapius cult in the $3^{\text {rd }}$ century AD as well as for the function of his temple in Dacia, compared to oriental religions and cults gaining ground in this period. Even more, the act of offering a replica of a body part had such a strong impact and popularity than survives even in our days, and after a millennia is dedicated at modern shrines and holy places, in some Roman Catholic and Greek-Russian Orthodox churches, where all kinds of ex-voto types can be found. ${ }^{48}$

\section{REFERENCES}

\section{ABBREVIATIONS}

AJH

ArcheoDoc

ReDIVA

Alicu 1985

AlICU 1994

Alicu 2006

Alicu-Cociș 1989

Alicu-Nemeș 1977

Alicu et al. 1979

Alicu-Rusu-Pescaru 2000

ANTAL 2014

Aparaschivei 2012

Lesk Blomerus 1999

Comella 1981

CRIŞAN 1970

DAICOVICIU et al. 1975

Daicoviciu-Alicu 1981

DeLPHINE 2014

DeONNA 1955
Athens Journal of Health, Athens

Journées doctorales de l'École doctorale d'archéologie, Sorbonne

Revista Doctoranzilor în Istorie Veche și Arheologie, Cluj-Napoca

= D. ALICU: Precizări privind cronologia unor lămpi ștampilate de la Sarmizegetusa [Details regarding the chronology of some stamped lamps from Sarmizegetusa]. Apulum 22 (1985) 77-87.

= D. Alicu: Opaițele romane - Die Römischen Lampe. Ulpia Traiana Sarmizegetusa. București 1994.

= D. Alicu: Die Römischen Lampen von Sarmizegetusa. I. Zalău 2006.

= D. ALICU-S. Cocış: Instrumente medicale de la Ulpia Traiana Sarmizegetusa. Apulum 26 (1989) 223-236.

= D. Alicu-E. Nemeș: Roman Lamps from Sarmizegetusa. BAR IntSer 18. Oxford 1977.

= D. Alicu-C. Pop-V. Wollmann: Figurated Monuments from Sarmizegetusa. BAR 55. Oxford 1979.

= D. Alicu-A. Rusu-Pescaru: Templele romane din Dacia (I) [Roman Temples in Dacia]. Deva 2000.

= A. ANTAL: A god of convalescence. Telesphorus/Genius Cucullatus in Roman Dacia. AMN 51/1 (2014) 195-206.

= D. Aparaschivei: Healthcare and Medicine in Moesia Inferior. Iași 2012.

$=\mathrm{A}$. L. Lesk Blomerus: The Anatomical Votive Terracotta Phenomenon: Healing sanctuaries in the Etrusco-Latial Campanian region during the fourth through first centuries B.C. [Diss.] University of Cincinnati 1999.

= A. Comella: Tipologia e diffusione dei complessi votive in Italia in epoca medio e tardo repubblicana: Contributo alla storia dell'artigianto antico. MEFRA 93 (1981) 717-803.

= E. CRIȘAN: Ex voto-uri anatomice de la Veii în Muzeul de Istorie Cluj [Anatomical ex-voto from Veii in the History Museum Cluj]. AMN 7 (1970) 489-497.

$=$ H. Daicoviciu-D. Aalicu-E. NeMEŞ-I. PISO-C. PoP-A. Rusu: Principalele rezultate ale săpăturilor din 1973-1974 la Ulpia Traiana Sarmizegetusa și semnificația lor [The main results of excavations between 1973-1974 at Ulpia Traiana Sarmizegetusa and their signification]. Sargetia 11-12 (1975) 225-233.

= H. DAICoviciu- D. Alicu: Edificii de cult la Ulpia Traiana [Worship buildings at Ulpia Traiana]. AMN 18 (1981) 59-84.

$=\mathrm{F}$. DeLPHINE: Les représentations anatomiques dans les sanctuaires de la Gaule romaine $\left(\mathrm{I}^{\mathrm{er}}-\mathrm{IV}^{\mathrm{e}} \mathrm{s}\right.$. apr. J.-C.): pratiques gréco-romaines et traditions celtes. ArcheoDoc 5 (2014) 49-65.

= W. Deonna: Télesphore et le ,genius cucullatus” celtique. Latomus 14 (1955) 43-74. 
EDELSTEIN 1945

ENE 2014

FLOCA 1967

GIRONE 1998

GRADVOHL 2006

GRAHAM-DRAYCOTT 2017

GRIFFITH 2013

HugHes 2017

IGNA 1935

KÁDÁR 1989

NiCOLAUs 1981

OBERHELMAN 2014

PAKI-COCIS 1987

Petridou 2016

PISO 2001

RENBERG 2006

RENBERG 2007

SCHÄFER 2007

SZABÓ 2004

SzABó 2008

SZABÓ 2015

UNGUREAN 2008

VARGA 2005

VARGA 2015
= E. J. EdelsteIn: Asclepius: Collection and Interpretation of the Testimonies. I. Baltimore 1945.

= S. E. I. EnE: Arta coroplastică in provincia Dacia (sec. II-III p.Chr.) [Coroplastic Art in the Province of Dacia $\left(2^{\text {nd }}-3^{\text {rd }}\right.$ c. A.D.]. PhD Thesis University of Bucharest. București 2014

= O. FlocA: Muzeul de Arheologie Ulpia Traiana Sarmizegetusa [Archaeology Museum of Ulpia Traiana Sarmizegetusa]. Deva 1967.

= M. GIRONE: 'Í́ $\mu \alpha \tau \alpha$. Guarigioni miracolose di Asclepio in testi epigrafici. Bari 1998.

= E. Gradvohl: Votive uteri in the Hungarian National Museum. In: Ancient Medicine and Pannonia. Studies in medical practice in Antiquity. Eds: P. Zsidi, G. Németh. Budapest 2006, 33-38.

= E. J. GRAHAM-J. DRAYCotT: Introduction: Debating the anatomical votive. In: Bodies of Evidence. Ancient anatomical votives past, present and future. Eds: E. J. Graham, J. Draycott. London-New York 2017, 1-19.

= A. GRIFFITH: Reconstructing religious ritual in Italy. In: A Companion to the Archaeology of the Roman Republic. Eds. J. D. Evans. New York 2013, 235-250.

$=$ J. Hughes: Votive Body Parts in Greek and Roman Religion. Cambridge 2017.

= N. IGNA: Cultul lui Esculap și al Higiei, cu specială privire la Dacia Superioară [Esculap and Higia Cult, with special Regards to Upper Dacia]. Cluj-Napoca 1935.

= K. KÁDÁR: Der Kult der Heilgötter in Pannonien und den übrigen Donauprovinzen. ANRW 18/2. Berlin-New York 1989, 1038-1061.

= J. Nicolaus: Asklepionul din Ulpia Traiana Sarmizegetusa [The Asklepion of Ulpia Traiana Sarmizegetusa]. Sargetia 15 (1981) 43-85.

= S. M. OBERHELMAN: Anatomical votive reliefs as evidence for specialization at healing sanctuaries in the Ancient Mediterranean World. AJH 1/1 (2014) 47-62.

= A. PAKI-S. Cociș: Teracote de la Ulpia Traiana Sarmizegetusa [Terracottas from Ulpia Traiana Sarmizegetusa]. Sargetia 20 (1987) 480-487.

= G. Petridou: Healing shrines. In: A Companion to Science, Technology, and Medicine in Ancient Greece and Rome. Ed.: G. L. Irby. Chichester 2016, 434-449.

= I. PISO: Inscriptions d'Apulum. Paris 2001 .

= G. H. RENBERG: Was incubation practiced in the Latin West? In: Archiv für Religionsgeschichte. Hrsg.: J. Assmann, F. Graf, T. Hölscher, L. Koenen, J. Scheid. Leipzig 2006, 105-147.

$=$ G. H. RENBERG: Public and private places of worship in the cult of Asclepius at Rome. MAAR 51/52 (2007) 87-172.

= A. SCHÄFER: Tempel und Kult in Sarmizegetusa. Marsberg, Padberg 2007.

= Á. SzABó: Az Apulumi Locus. Vázlat egy szentélykörzetröl (Der Locus von Aquincum. Skizze von einer Heiligtumsregion). FolArch 51 (2004) 91-114.

= Á. SzABÓ: Aesculapius és az álom általi gyógyítás Daciában [Aesculapius and the 'healing by incubatio' in Dacia]. In: A gyógyító számok. Források és tanulmányok a számok szerepéröl az antik gyógyászatban. Ed.: G. Németh. Szeged 2008, 99-110.

= Cs. Szabó: Placing the gods. Sanctuaries and sacralized spaces in the settlements of Apulum. ReDIVA 3 (2015) 123-160.

$=$ O. UngurEAN: Teracote figurate in Dacia Romană [Figurative terracottas from Roman Dacia]. PhD Thesis Babeş-Bolyai University Cluj-Napoca. Cluj-Napoca 2008.

$=$ R. VARGA: Locuri de cult ale zeilor taumaturgi în Dacia romană [Places for worshiping healing gods in Roman Dacia]. Chronos 3/2(5) (2005) 5-8.

= T. VARGA: Hypnos and the incubatio ritual at Ulpia Traiana Sarmizegetusa. AMP 37 (2015) 241-251. 
